Published in final edited form as:

Neurochem Int. 2008 January ; 52(1-2): 142-154.

\title{
Mechanisms of glutamate release from astrocytes
}

\author{
Erik B. Malarkey and Vladimir Parpura ${ }^{1}$ \\ Departments of Cell Biology \& Neuroscience, Centers for Glial-Neuronal Interactions and Nanoscale Science \\ \& Engineering, University of California, Riverside, CA 92521 \\ 1 Departments of Physics \& Astronomy, Centers for Glial-Neuronal Interactions and Nanoscale Science \& \\ Engineering, University of California, Riverside, CA 92521
}

\begin{abstract}
Astrocytes can release the excitatory transmitter glutamate which is capable of modulating activity in nearby neurons. This astrocytic glutamate release can occur through six known mechanisms: (i) reversal of uptake by glutamate (ii) anion channel opening induced by cell swelling, (iii) $\mathrm{Ca}^{2+}$ dependent exocytosis, (iv) glutamate exchange via the cystine-glutamate antiporter, (v) release through ionotropic purinergic receptors and (vi) functional unpaired connexons, 'hemichannels', on the cell surface. Although these various pathways have been defined, it is not clear how often and to what extent astrocytes employ different mechanisms. It will be necessary to determine whether the same glutamate release mechanisms that operate under physiological conditions operate during pathological conditions or whether there are specific release mechanisms that operate under particular conditions.
\end{abstract}

\section{Keywords}

glutamate release; exocytosis; transporters; P2X receptors; connexin "hemichannels"; anion channels

\section{Introduction}

Astrocytes can release a variety of neuroligands into the extracellular space using many different mechanisms. The first demonstration of this astrocytic ability was of primary cultured astrocytes releasing taurine upon $\beta$-adrenergic stimulation (Shain and Martin, 1984). In this review we focus on the release of the excitatory neurotransmitter glutamate. This transmitter can be released from astrocytes by several different mechanisms: (i) reversal of uptake by plasma membrane glutamate transporters (Szatkowski et al., 1990), (ii) anion channel opening induced by cell swelling (Kimelberg et al., 1990), (iii) $\mathrm{Ca}^{2+}$-dependent exocytosis (Parpura et al., 1994), (iv) glutamate exchange via the cystine-glutamate antiporter (Warr et al., 1999), (v) release through ionotropic purinergic receptors (Duan et al., 2003) and (vi) functional unpaired connexons, 'hemichannels', on the cell surface (Ye et al., 2003). We discuss studies using variety of different approaches which provided evidence for the different mechanisms of glutamate release in astrocytes. While $\mathrm{Ca}^{2+}$-dependent vesicular release of glutamate from astrocytes can readily occur under physiological conditions, there is some question as to

Correspondence: Vladimir Parpura, Department of Cell Biology \& Neuroscience, Center for Glial-Neuronal Interactions, 1208 Spieth Hall, University of California, Riverside, CA 92521, Phone/Fax: (951) 827-2074, E-mail: vlad@ucr.edu.

Publisher's Disclaimer: This is a PDF file of an unedited manuscript that has been accepted for publication. As a service to our customers we are providing this early version of the manuscript. The manuscript will undergo copyediting, typesetting, and review of the resulting proof before it is published in its final citable form. Please note that during the production process errors may be discovered which could affect the content, and all legal disclaimers that apply to the journal pertain. 
whether some mechanisms might solely operate during pathophysiological circumstances, such as ischemia or stroke, since they may require conditions like cell swelling or a low extracellular $\mathrm{Ca}^{2+}$ concentration $\left(\left[\mathrm{Ca}^{2+}\right]_{0}\right)$ to occur. An understanding of these mechanisms and conditions that underlie glutamate release will provide information on glial functions in heath and disease and may also introduce opportunities for medical intervention.

\section{$\mathrm{Ca}^{2+}$ - dependent exocytosis}

The first evidence for $\mathrm{Ca}^{2+}$ - dependent release of glutamate from cultured astrocytes was shown in experiments using high performance liquid chromatography, where bradykinin-evoked intracellular $\mathrm{Ca}^{2+}$ elevations in cultured astrocytes resulted in the release of glutamate. This release could also be visualized by N-methyl-D-aspartic acid (NMDA) receptor-mediated intracellular $\mathrm{Ca}^{2+}$ increases in surrounding neurons (Parpura et al., 1994). An increase in intracellular $\mathrm{Ca}^{2+}$ concentration $\left(\left[\mathrm{Ca}^{2+}\right]_{\mathrm{i}}\right)$ is sufficient and necessary to cause glutamate release form astrocytes. Hence, when the $\mathrm{Ca}^{2+}$ ionophore, ionomycin, was applied to astrocytes it stimulated the release of glutamate in the presence of external free $\mathrm{Ca}^{2+}(2.4 \mathrm{mM})$. However, ionomycin failed to cause glutamate release when internal $\mathrm{Ca}^{2+}$ stores were depleted by preventing $\mathrm{Ca}^{2+}$ entry from the extracellular space by bathing the astrocytes in a solution of low external free $\mathrm{Ca}^{2+}(24 \mathrm{nM})$ for 40-60 minutes (Parpura et al., 1994). Further studies supported this conclusion since buffering cytoplasmic $\mathrm{Ca}^{2+}$ with 1,2-bis(o-aminophenoxy) ethane-N,N, $\mathrm{N}^{\prime}, \mathrm{N}^{\prime}$-tetraacetic acid (BAPTA) or depleting internal calcium stores by application of thapsigargin, a blocker of store specific $\mathrm{Ca}^{2+}$-ATPase, also resulted in a reduction of glutamate release (Araque et al., 1998b; Bezzi et al., 1998). Using flash photolysis of a caged $\mathrm{Ca}^{2+}$ compound to evoke graded rises of cytoplasmic $\mathrm{Ca}^{2+}$ concentration in astrocytes, demonstrated that glutamate release can result from moderate increases in $\mathrm{Ca}^{2+}$ concentration that are likely to occur physiologically (Parpura and Haydon, 2000). Indeed, supporting evidence for $\mathrm{Ca}^{2+}$-dependent glutamate release was, subsequently, established in acute slice preparations (Bezzi et al., 1998). Additionally, this release mechanism was determined to be distinct from swelling or reverse operation of plasma membrane glutamate transporters since no change in astrocyte volume was detected and glutamate transporter inhibitors did not abolish the release (Parpura et al., 1995b; Jeftinija et al., 1996; Araque et al., 2000; Innocenti et al., 2000).

$\mathrm{The} \mathrm{Ca}^{2+}$ necessary for this glutamate release comes from two sources. The majority originates from internal stores, but entry of external $\mathrm{Ca}^{2+}$ is also involved. This was demonstrated by the reduction of mechanically-induced glutamate release in the presence of thapsigargin and also by $\mathrm{Cd}^{2+}$, a blocker of $\mathrm{Ca}^{2+}$ entry from the extracellular space (Hua et al., 2004). This release requires co-activation of inositol 1,4,5-trisphosphate $\left(\mathrm{IP}_{3}\right)$ - and ryanodine/caffeine-sensitive internal $\mathrm{Ca} 2+$ stores, which operate jointly (Hua et al., 2004). Currently, the identity of the mechanism mediating $\mathrm{Ca}^{2+}$ entry from the extracellular space, involved with mechanicallyinduced glutamate release in astrocytes is unresolved. Transient receptor potential (TRP) proteins, which are believed to be activated by depletion of internal $\mathrm{Ca}^{2+}$ stores to allow $\mathrm{Ca}^{2+}$ entry from the extracellular space, have been implicated in the regulation of astrocytic $\mathrm{Ca}^{2+}$ homeostasis (Pizzo et al., 2001; Grimaldi et al., 2003; Golovina, 2005; Malarkey and Parpura, 2005); naturally, these proteins are the prime candidates for mediating the entry of external $\mathrm{Ca}^{2+}$ in mechanically-induced glutamate release from astrocytes.

$\mathrm{The} \mathrm{Ca}^{2+}$-dependency of glutamate release from astrocytes suggests regulated exocytosis as a possible mechanism underlying this release. Astrocytes possess the secretory machinery for regulated exocytosis which utilizes a complex of proteins, the soluble N-ethyl maleimidesensitive fusion protein attachment protein receptor (SNARE) complex, to control vesicle fusion [for review see (Montana et al., 2004)]. This includes proteins of the core SNARE complex: synaptobrevin 2, Syntaxin 1 and synaptosome-associated protein of $23 \mathrm{kDa}$ 
(SNAP-23) (Parpura et al., 1995a; Jeftinija et al., 1997; Hepp et al., 1999; Maienschein et al., 1999; Araque et al., 2000; Pasti et al., 2001; Montana et al., 2004; Crippa et al., 2006) and a

$\mathrm{Ca}^{2+}$ sensor Synaptotagmin 4 (Zhang et al., 2004a; Crippa et al., 2006). Proteins important for sequestering of glutamate into vesicles have also been discovered in astrocytes. Vacuolar type $\mathrm{H}^{+}$-ATPase (V-ATPase), which creates the proton concentration gradient necessary for glutamate transport into vesicles (Araque et al., 2000; Bezzi et al., 2001; Pasti et al., 2001; Montana et al., 2004; Wilhelm et al., 2004); (Crippa et al., 2006) and the three known isoforms of vesicular glutamate transporters (VGLUT): 1,2 and 3, which use the proton gradient created by V-ATPases to package glutamate into vesicles (Fremeau et al., 2002; Bezzi et al., 2004; Kreft et al., 2004; Montana et al., 2004; Zhang et al., 2004b; Anlauf and Derouiche, 2005; Crippa et al., 2006), have been detected in astrocytes and play a functional role in mediating $\mathrm{Ca}^{2+}$-dependent glutamate release from astrocytes (Figure 1A, Table 1). The action of specific pharmacological agents and molecular biological manipulations that affect glutamatergic exocytosis was confirmed in astrocytes [reviewed in (Montana et al., 2004)]

The presence of vesicular proteins in astrocytes, including VGLUTs, implies that astrocytes release glutamate via a vesicular pathway. Such a notion requires evidence of the existence of astrocytic secretory vesicles, since these organelles are the essential morphological elements for regulated, $\mathrm{Ca}^{2+}$-dependent exocytosis. Secretory granules in the glia of grey matter were described nearly 100 years ago (Nageotte, 1910). However, only recently, has there been compelling evidence for morphological correlates of the exocytotic process underlying glutamate release in astrocytes [reviewed in (Montana et al., 2004)]. An immunoelectron microscopy (IEM) study demonstrated that synaptobrevin 2 could be associated with electronlucent (clear) vesicular structures with diameters ranging from 100-700 nm (Maienschein et al., 1999). The IEM of VGLUTs 1 or 2 in astrocytes in situ showed an association of these proteins with small clear vesicles with a mean diameter of $\sim 30 \mathrm{~nm}$ (Bezzi et al., 2004). Additionally, VGLUT 2 was found on synaptobrevin 2-containing vesicles immunoisolated from cultured astrocytes (Crippa et al., 2006). These vesicles were shown to be predominantly clear and heterogeneous in size, ranging from 30 to over $100 \mathrm{~nm}$. Furthermore, the presence of clear smooth and clathrin-coated vesicles with apparent diameters of $\sim 30 \mathrm{~nm}$ has been observed in gliosomes, a purified preparation of re-sealed fragments of astrocytes from the adult rat brain (Stigliani et al., 2006), which expressed synaptobrevin 2 and VGLUT 1.

The delivery of small synaptic-like vesicles to plasma membrane exocytotic sites has been investigated in astrocytes. Crippa et al. (2006) expressed chimeric protein where enhanced green fluorescent protein (EGFP) was fused to the C-terminus of synaptobrevin 2 (synaptobrevin 2-EGFP) in astrocytes. Synaptobrevin 2-EGFP, disclosing the location of small vesicles, showed a punctate pattern of fluorescence throughout the cells. These astrocytic vesicles displayed mobility behavior similar to that of synaptic vesicles in neurons. When astrocytes were stimulated to exhibit regulated exocytosis, many fluorescent synaptobrevin 2EGFP puncta disappeared with a concomitant increase in plasma membrane fluorescence, consistent with full fusion of labeled vesicles. During the process of exocytosis, there is a net addition of vesicular membrane to the plasma membrane, which can be directly assessed by monitoring changes in plasma membrane capacitance $\left(\mathrm{C}_{\mathrm{m}}\right)$. Consequently, stimulation to increase $[\mathrm{Ca} 2+]_{\mathrm{i}}$ in astrocyte using $\mathrm{t}-\mathrm{ACPD}$ caused an increase $\mathrm{C}_{\mathrm{m}}$, while simultaneous measurements recorded release of glutamate (Zhang et al., 2004b). Further evidence for vesicular exocytosis from astrocytes was provided by Bezzi et al. (2004). Using total internal refection fluorescence microscopy, they followed up on the spatio-temporal characteristics of exocytosis of VGLUT positive vesicles. Similarly, glutamatergic exocytosis in astrocytes has been demonstrated by amperometric measurements used to detect the release of dopamine, acting as a "surrogate" transmitter for glutamate, from glutamatergic vesicles (Chen et al., 2005). Finally, the process of exocytosis is characterized by quantal release of neurotransmitter 
(Del Castillo and Katz, 1954) and quantal-like events of glutamate release have been recorded from astrocytes (Pasti et al., 2001)

Future experiments will be needed to define the location of the exocytotic release sites in vivo and the contribution of this release from astrocytes to the physiology and pathophysiology of the central nervous system. One of the emerging functions in which this release may play a role is the spatial coordination and synchronization of neuronal activity and synaptic networks (Angulo et al., 2004; Fellin et al., 2004; Pascual et al., 2005).

\section{Reverse operation of glutamate transporters}

An important function that astrocytes perform is the removal of glutamate from extracellular space. This function is accomplished through the use of plasma membrane $\mathrm{Na}^{+}$-dependent amino acid transporters which couple the transport of $\mathrm{Na}^{+}$and $\mathrm{K}^{+}$down their respective concentration gradients to driving glutamate into the cell (Anderson and Swanson, 2000). The majority of glutamate transporters found in astrocytes are associated with synapses (Chaudhry et al., 1995; Minelli et al., 2001). Hence, the removal of glutamate from the extracellular space by astrocytes aids in termination of synaptic neurotransmission and prevents excitotoxicity (Rothstein et al., 1996; Bergles and Jahr, 1997).

Astrocytes predominantly express two transporters that are used in this process: the Lglutamate/L-aspartate transporter (GLAST-1) and the glial L-glutamate transporter (GLT-1), also called excitatory amino acid transporters (EAAT1 and EAAT2, respectively) (Gadea and Lopez-Colome, 2001). Normally, concentration gradients favor the transport of glutamate into astrocytes. However, during pathophysiological events, such as ischemia, perturbed ionic conditions (e.g. increased extracellular $\mathrm{K}^{+}$levels) may favor transporters operating in reverse (Figure 1B). Transport reversal was first demonstrated in glial cells by measuring glutamate induced currents while raising extracellular $\mathrm{K}^{+}$levels (Szatkowski et al., 1990). Although it has been shown that under normal physiological conditions, extracelluar $\mathrm{K}^{+}$levels could not be elevated enough to cause reverse transport of glutamate out of cultured astrocytes (Longuemare and Swanson, 1997), there have been numerous cases, using glutamate transporter inhibitors, showing that reverse transport of glutamate can occur during periods of ischemia or metabolic blockade (Longuemare and Swanson, 1995; Zeevalk et al., 1998; Li et al., 1999; Seki et al., 1999; Rossi et al., 2000) (Table 1). Accordingly, by using the EAAT substrate inhibitor L-trans-pyrrolidine-2,4-dicarboxylate (PDC) to induce glutamate release by heteroexchange (Volterra et al., 1996), reverse transport was shown to be a major event leading to cell death in astrocytes (Re et al., 2006). However, cell death was not caused by the increase in extracellular glutamate, but by the depletion of cytoplasmic glutathione resulting from the loss of glutamate inside the cell, which then leads to oxidative death.

\section{Cystine-glutamate antiporter}

Cystine uptake in cells is important for the production of the antioxidant, glutathione. Uptake can occur through either the plasma membrane $\mathrm{Na}^{+}$-independent cystine-glutamate exchanger (system $\mathrm{x}_{\mathrm{c}^{-}}$) or the $\mathrm{Na}$--dependent glutamate transporters (system $\mathrm{X}_{\mathrm{AG}^{-}}$) [reviewed in (McBean, 2002)]. Although results differ in the amount of uptake contributed by each process, astrocytes have been shown to utilize both of them in cystine uptake (Bender et al., 2000; Allen et al., 2001; Shanker et al., 2001). The majority of cystine-glutamate exchanger localization in the brain occurs in glial cells (Pow, 2001) as revealed by immunolocalization of aminoadipic acid, a selective substrate for this exchanger.

Since the $\mathrm{x}_{\mathrm{c}}$ - system functions by importing cystine in exchange for glutamate, this may provide a pathway for glutamate release from astrocytes (Figure 1C, Table 1) This has been initially demonstrated in cerebellar slices, where addition of cystine to the extracellular space generated 
currents in Purkinje cells. These currents were attributed to glutamate released from glia, since the currents were abolished by glutamate receptor antagonists and were not seen in isolated Purkinje cells (Warr et al., 1999). Applying homocysteic acid or (S)-4-carboxyphenylglycine (CPG) to block the cystine-glutamate exchanger decreased the extracellular glutamate concentration in rat striatum by $60 \%$ (Baker et al., 2002). Agonists or antagonists of mGluR2 receptors were shown to down- or up-regulate, respectively, glutamate release by the cystineglutamate exchanger (Tang and Kalivas, 2003) and the glutamate released through the cystineglutamate exchanger has also been shown to reduce both spontaneous and action-potential evoked glutamate release, again, by action on mGluR2, although in a brain region dependent manner (Moran et al., 2003).

Cavelier and Atwell (2005) have raised questions of whether tonic release of glutamate through the $\mathrm{x}_{\mathrm{c}^{-}}$system occurs under normal physiological conditions. They found that blocking the cystine-glutamate exchanger had no effect on glutamate release unless unphysiologically high levels of external cystine were present. They also pointed out that physiological levels of intercellular cystine found in the brain were well below the reported $\mathrm{EC}_{50}$ of the exchanger [(Warr et al., 1999), but see (Baker et al., 2003)]. However, the role of glutamate release by the cystine-glutamate exchanger in vivo has been demonstrated by Moran et al. (2005). Here first using acute slices the authors found that application of physiological levels of cystine (100-300 nM) could elevate extracellular glutamate concentrations and reduce excitatory synaptic activity; this effect was blocked by application of CPG or the mGluR2/3 antagonist LY341495. Since a reduction in extracellular glutamate by withdrawal from cocaine is attributed to compromised $\mathrm{x}_{\mathrm{c}^{-}}$system function (Baker et al., 2003), behavioral studies with rats were performed (Moran et al., 2005). Restoring extracellular glutamate with systemic administration of cysteine prodrugs prevented the reinstatement of cocaine seeking and this effect was reversed by the application of mGlur $2 / 3$ antagonist, indicating that glutamate released via the $\mathrm{x}_{\mathrm{c}}$ - system stimulates inhibitory presynaptic $\mathrm{mGluR} 2 / 3$ receptors which reduce synaptic glutamate release, preventing drug seeking. Conversely, inhibiting the function of the cystine-glutamate exchanger with CPG or by removing extracellular cystine, has been shown to cause cell death in astrocytes, presumably by oxidative death due to lack of cystine to convert to glutathione (Re et al., 2006). A similar approach was employed for possible clinical benefit by using sulfasalazine to block system $\mathrm{x}_{\mathrm{c}^{-}}$in gliomas. This treatment reduced the levels of intracellular glutathione and consequently caused oxidative cell death that resulted in a reduction in growth of gliomas (Chung et al., 2005).

\section{$\mathrm{P}_{2} \mathrm{X}_{7}$ receptors}

The purinergic $\mathrm{P} 2 \mathrm{X}_{7}$ ion channel may provide another pathway for glutamate release from astrocytes. P2X receptors are adenosine 5'-triphosphate (ATP)-gated, cation selective, ion channels that show amplified responses in low external divalent cation solution. There are seven known types of $\mathrm{P} 2 \mathrm{X}$ receptor subunits that can assemble to from homomeric or heteromeric channels. The homomeric $\mathrm{P} 2 \mathrm{X}_{7}$ receptor possesses a pore that is able to allow molecules as large as $900 \mathrm{Da}$ to pass through (North, 2002). The $\mathrm{P}_{2} \mathrm{X}_{7}$ receptor has been detected in astrocytes in vitro by RT-PCR (Fumagalli et al., 2003), immunoblotting and immunolocalization (Duan et al., 2003), and there is indication that they may be up-regulated after injury (Franke et al., 2001). $\mathrm{P} 2 \mathrm{X}_{7}$ receptors have also been detected in astrocytes in vivo using hippocampal sections of juvenile rats (Kukley et al., 2001). Astrocytic localization was determined by immunocytochemistry using antibodies against $\mathrm{P} 2 \mathrm{X}_{7}$, along with $\mathrm{S} 100 \beta$ as an astrocytic marker.

Duan et al. (2003) provided the first evidence that these channels could mediate the release of glutamate from astrocytes. Application of ATP to cultured astrocytes expressing P2 $\mathrm{X}_{7}$ receptors induced an inward current that was augmented by low divalent cation external 
solution. Activation of these receptors enabled astrocytic uptake of the fluorescent dye, Lucifer Yellow (LY), which was also increased in low divalent cation external solution. Current or dye uptake was inhibited by the $\mathrm{P} 2$ receptor antagonist, pyridoxal phosphate-6-azophenyl-2-4disulfonic acid (PPADS), the anion channel blocker, DIDS, or the more specific $\mathrm{P}_{2} \mathrm{X}_{7}$ antagonist, oxidized ATP (oATP). The induced current was also insensitive to voltage changes, which differentiates it from channels such as gap junctions. Release of radiolabeled glutamate was induced by application of ATP, but more potently with 3'-O-(4-benzoyl)benzoyl ATP (BzATP), and increased in low divalent cation solution, consistent with release through the $\mathrm{P}_{2} \mathrm{X}_{7}$ channel, while PPADS, DIDS or oATP blocked its release. This glutamate release does not seem to occur by a mechanism that requires $\left[\mathrm{Ca}^{2+}\right]_{\mathrm{i}}$ increase since preincubating the cells with the membrane permeable calcium chelator, acetoxymethyl ester of BAPTA, did not reduce the amount of released glutamate.

In hippocampal slices, Fellin et al. (2006) found that perfusion of BzATP induced transient slow inward currents (SICs) and tonic currents in pyramidal neurons that resulted from NMDA receptor activation. The currents were induced by glutamate release from astrocytes, since they occurred in the presence of tetrodotoxin. The tonic current, but not SICs, appeared to be mediated by glutamate release from $\mathrm{P} 2 \mathrm{X}_{7}$-like receptors as it was blocked by the $\mathrm{P} 2 \mathrm{X}$ antagonists, oATP and Brilliant Blue G (BBG) and were enhanced in low $\mathrm{Ca}^{2+}$ external solution. Glutamate release through transporter reversal or hemichannels was ruled out since the glutamate transporter inhibitor, DL-threo- $\beta$-benzyloxyaspartate (TBOA), or carbenoxolone did not affect the tonic current. In astrocytes BzATP induced an inward current that was blocked by BBG and not affected by any glutamate receptor antagonists, so the current did not result from released glutamate. BzATP was also able to induce uptake of LY in astrocytes, which was again blocked by BBG. This work indicates that ATP in situ can cause release of glutamate from astrocytes through $\mathrm{P} 2 \mathrm{X}$ receptors that provide tonic stimulation of surrounding neurons.

\section{Swelling/anion channels}

Under hypo-osmotic conditions, such as those occurring during ischemia, most cells experience swelling and can compensate for this volume increase by opening volume-regulated anion channels (VRACs). These channels are permeable to inorganic and small organic anions, including the amino acids taurine, aspartate and glutamate (Mongin and Orlov, 2001). Release of glutamate from cultured astrocytes during hypo-osmotically induced swelling was first reported by Kimelberg et al. (1990) using radiolabled glutamate. They found that this release of glutamate occurred through an anion channel since it could be blocked by various anion channel inhibitors (Figure 1E, Table 1). Another study showed that glutamate released from astrocytes contributed to spreading depression in hippocampal slices. This glutamate was released in $\mathrm{Ca}^{2+}$ free medium but blocked by 5-nitro-2-(3-phenylpropylamino) benzoic acid (NPPB), a $\mathrm{Cl}^{-}$channel inhibitor, indicating that glutamate could have been released through VRACs (Basarsky et al., 1999). Liu et al. (2006) discerned swelling induced glutamate release from two different anion channels, the volume-sensitive outwardly rectifying (VSOR) chloride channels and the maxi-anion channels. Using hyposmotic solution or inducing metabolic arrest resulted in release of glutamate from atrocytes that was not mediated by hemichannels or vesicular release. Using cell attached patches they found channels with large conductance that were insensitive to phloretin but inhibited by $\mathrm{Gd}^{3+}$, representative of maxi-anion channels. The swelling- and ischemia-induced release of glutamate was greatly suppressed by blockers of maxi-anion channels such as NPPB, 4-acetamido-4'-isothiocyanato-stilbene-2,2'-disulfonate (SITS), $\mathrm{Gd}^{3+}$, and arachidonic acid. This result strongly suggests that the maxi-anion channel is the major contributor to the release of glutamate from cultured astrocytes. However, not all glutamate release was prevented by blockers of maxi-anion channels and whole cell and cell 
attached patch currents indicative of VSOR were detected which were blockable by phloretin and tamoxifen.

There have been many reports that astrocytes can release amino acids during pathologically induced swelling [reviewed in (Kimelberg, 2005)], but non-pathological glutamate release through VRACs has not been demonstrated. The small amount of volume change that may occur in astrocytes under physiological conditions seems insufficient to cause significant glutamate release. However, it has been shown that compounds such as ATP (Mongin and Kimelberg, 2002, 2005; Takano et al., 2005) or nitric oxide (Ellershaw et al., 2000) can act on VRACs to amplify amino acid release under conditions of only moderate swelling or hypoosmolarity which could possibly occur in vivo. There is evidence that receptor mediated intracellular $\mathrm{Ca}^{2+}$ increases, induced by ATP in astrocytes, can result in transient cell swelling leading to glutamate release through VRACs (Takano et al., 2005). Using whole-cell recoding, application of ATP caused the opening of channels which, along with glutamate release, was reduced by BAPTA and the anion channel blockers: NPPB, flufenamic acid and gossypol, but neither a glutamate transporter inhibitor nor two compounds known to affect vesicular release, tetanus toxin and bafilomycin A1. Glutamate release did not appear to be through $\mathrm{P} 2 \mathrm{X}_{7}$ channels since BzATP had no effect and the channels were not cation selective. Also connexin hemichannels, most likely, did not play a role since ATP-induced glutamate release was similar in astrocytes from $\mathrm{Cx} 43$ knockout and wild type mice.

Determining conclusively that glutamate is released through VRACs has proven complicated due to a lack of specific inhibitors of suspected pathways. For example, many of the anion channel inhibitors used have been shown to block connexin hemichannels (Eskandari et al., 2002). Further, the anion channel blockers used in most studies of VRACs have been reported to act on a variety of other channels. For example, NPPB can inhibit the vesicular chloride transporter and 4,4'-diisothiocyanato-stilbene-2,2'-disulfonate (DIDS) has been implicated in blocking VGLUTs and V-ATPases (reviewed in Evanko et al., 2004)]. Although buffering cytoplasmic $\mathrm{Ca}^{2+}$ can interfere with osmotically-induced amino acid release from astrocytes (Mongin et al., 1999), tetanus toxin had no effect on swelling-induced release, indicating that this release does not appear to be through a vesicle mediated pathway (Mongin and Kimelberg, 2002). This also emphasizes how difficult it can be to isolate the effects of one release mechanism from another.

\section{Connexons/Pannexons}

Gap junction channels form a pore between two adjacent cells, connecting their cytoplasm, and allowing molecules as large as about $1 \mathrm{kDa}$ to diffuse between cells. These gap junctions are formed by the joining of two connexons ("hemichannels") each composed of a hexamer of the protein connexin. Although there are many different isoforms of connexin, $\mathrm{Cx} 43$ appears to be the most prevalent in astrocytes (Dermietzel et al., 2000). There is evidence that unpaired connexons may be able to act as functional hemichannels, capable of opening to the external space (Hofer and Dermietzel, 1998; Contreras et al., 2002; Stout et al., 2002; Ye et al., 2003).

Since these hemichannels can pass large molecules, then their opening could provide a mechanism whereby transmitters such as glutamate could diffuse out of astrocytes (Figure 1F, Table 1). There has been some evidence supporting this kind of release through hemichannels for glutamate release (Ye et al., 2003). Ye et al. (2003) found that under conditions of low extracellular divalent cations, hippocampal astrocytes showed release of glutamate. This release, and also LY dye uptake, was reduced by application of the gap junction blockers, carbenoxolone, heptanol, octanol and $18 \alpha$-glycyrrhetinic acid, as well as by multivalent cations. However, release was not inhibited by the P2X receptor blockers, oATP and PPADS or the chloride channel blocker, DIDS. This seems consistent with release through hemichannels, but, as stated above, many compounds used as gap junction blockers have been 
shown to affect anion channels as well (Eskandari et al., 2002). Several channels could provide a means for the glutamate release form astrocytes attributed to connexin hemichannels: pannexins, P2X receptors and also various anion channels such as, voltage dependent anion conductance (VDAC), cystic fibrosis transmembrane conductance regulator (CTFR), or VSOR have all been shown to operate under similar conditions and respond to chemical agents commonly used to manipulate hemichannels. Often, the involvement of hemichannels in mediating a given event is claimed using insufficient criteria, such as reduction of glutamate release using a gap junction blocker that is non-specific. A set of stringent criteria have been proposed in order to establish whether an observed effect should be attributed to hemichannels (for a discussion of this issue see: Spray et al., 2006)]. However, astrocytes cultured from Cx43 knock-out mice and exposed to low extracellular divalent cations show minimal LY dye uptake and glutamate release, when compared to astrocytes originating from control wild type animals (Spray et al., 2006). Such finding supports the notion that glutamate could, indeed, be released via connexin hemichannels. This may appear at odds with the voltage sensitivity of gap junction channels, which only open as membrane potentials become positive (Trexler et al., 1996), an event that normally does not occur with astrocytes. However, there is some evidence that hemichannels can be gated under resting conditions (Contreras et al., 2003; Saez et al., 2005). Whether release through hemichannels would occur during normal conditions in the brain, or perhaps only during injury or ischemia, still needs to be determined.

The pannexin family of proteins can also form conductive channels similar to the connexins. Non-junctional pannexin channels, "pannexons", are not sensitive to extracellular $\mathrm{Ca}^{2+}$ and can be opened by cytoplasmic $\mathrm{Ca}^{2+}$ elevations at membrane potentials within the range normally observed in astrocytes (Bruzzone et al., 2003). Pannexins are also sensitive to several of the same compounds used to block connexon hemichannels, such as carbenoxolone and flufenamic acid (Bruzzone et al., 2005). Many of the properties attributed to connexon hemichannels correlate well with those of pannexons, and with the detection of pannexin-1 (Pelegrin and Surprenant, 2006; Lai et al., 2007) 2 and 3 (Lai et al., 2007) RNA in astrocytes, pannexon hemichannels may have a role in mediating glutamate release from astrocytes.

\section{Concluding remarks}

The purpose of this review was to summarize the underlying mechanisms of glutamate release form astrocytes. There are several different mechanisms that can mediate glutamate release from these cells, as outlined in Figure 1, however, there are issues that remain to be resolved. It will be necessary to determine whether the same glutamate release mechanisms that operate under physiological conditions operate during pathological conditions or whether there are specific release mechanisms that operate under particular conditions. Alternatively, all possible mechanisms of glutamate release could operate together in astrocytes at all times, but each contributing a different portion to the total amount of glutamate being released. The major impediment in systematically conducting studies to address these issues is the absence of specific reagents and methods for teasing apart the contributions from individual release pathways, as was alluded to earlier. So far the most developed tools relate to the mechanism of exocytosis, this is owing to the over 50 years of work by many laboratories studying the exocytotic process in neurons. However, the development of novel genetic approaches that, for example, selectively manipulate exocytotic release from astrocytes (Pascual et al., 2005) or the use of $\mathrm{Cx} 43$ knock out animals provide good starting points to rigorously test the contribution of different glutamate release pathways in astrocytes in health and disease.

\section{Acknowledgements}

The authors' work is supported by a grant from the National Institute of Mental Health (MH 069791) and a grant from Department of Defense/Defense Microelectronics Activity under Award No. DOD/DMEA-H94003-06-2-0608. 


\section{References}

Allen JW, Shanker G, Aschner M. Methylmercury inhibits the in vitro uptake of the glutathione precursor, cystine, in astrocytes, but not in neurons. Brain Res 2001;894:131-140. [PubMed: 11245823]

Anderson CM, Swanson RA. Astrocyte glutamate transport: review of properties, regulation, and physiological functions. Glia 2000;32:1-14. [PubMed: 10975906]

Angulo MC, Kozlov AS, Charpak S, Audinat E. Glutamate released from glial cells synchronizes neuronal activity in the hippocampus. J Neurosci 2004;24:6920-6927. [PubMed: 15295027]

Anlauf E, Derouiche A. Astrocytic exocytosis vesicles and glutamate: a high-resolution immunofluorescence study. Glia 2005;49:96-106. [PubMed: 15390103]

Araque A, Parpura V, Sanzgiri RP, Haydon PG. Glutamate-dependent astrocyte modulation of synaptic transmission between cultured hippocampal neurons. Eur J Neurosci 1998a;10:2129-2142. [PubMed: 9753099]

Araque A, Sanzgiri RP, Parpura V, Haydon PG. Calcium elevation in astrocytes causes an NMDA receptor-dependent increase in the frequency of miniature synaptic currents in cultured hippocampal neurons. J Neurosci 1998b;18:6822-6829. [PubMed: 9712653]

Araque A, Li N, Doyle RT, Haydon PG. SNARE protein-dependent glutamate release from astrocytes. J Neurosci 2000;20:666-673. [PubMed: 10632596]

Baker DA, Xi ZX, Shen H, Swanson CJ, Kalivas PW. The origin and neuronal function of in vivo nonsynaptic glutamate. J Neurosci 2002;22:9134-9141. [PubMed: 12388621]

Baker DA, McFarland K, Lake RW, Shen H, Tang XC, Toda S, Kalivas PW. Neuroadaptations in cystineglutamate exchange underlie cocaine relapse. Nat Neurosci 2003;6:743-749. [PubMed: 12778052]

Bal-Price A, Moneer Z, Brown GC. Nitric oxide induces rapid, calcium-dependent release of vesicular glutamate and ATP from cultured rat astrocytes. Glia 2002;40:312-323. [PubMed: 12420311]

Basarsky TA, Feighan D, MacVicar BA. Glutamate release through volume-activated channels during spreading depression. J Neurosci 1999;19:6439-6445. [PubMed: 10414972]

Bender AS, Reichelt W, Norenberg MD. Characterization of cystine uptake in cultured astrocytes. Neurochem Int 2000;37:269-276. [PubMed: 10812212]

Bergles DE, Jahr CE. Synaptic activation of glutamate transporters in hippocampal astrocytes. Neuron 1997;19:1297-1308. [PubMed: 9427252]

Bezzi P, Gundersen V, Galbete JL, Seifert G, Steinhauser C, Pilati E, Volterra A. Astrocytes contain a vesicular compartment that is competent for regulated exocytosis of glutamate. Nat Neurosci 2004;7:613-620. [PubMed: 15156145]

Bezzi P, Carmignoto G, Pasti L, Vesce S, Rossi D, Rizzini BL, Pozzan T, Volterra A. Prostaglandins stimulate calcium-dependent glutamate release in astrocytes. Nature 1998;391:281-285. [PubMed: 9440691]

Bezzi P, Domercq M, Brambilla L, Galli R, Schols D, De Clercq E, Vescovi A, Bagetta G, Kollias G, Meldolesi J, Volterra A. CXCR4-activated astrocyte glutamate release via TNFalpha: amplification by microglia triggers neurotoxicity. Nat Neurosci 2001;4:702-710. [PubMed: 11426226]

Bruzzone R, Barbe MT, Jakob NJ, Monyer H. Pharmacological properties of homomeric and heteromeric pannexin hemichannels expressed in Xenopus oocytes. J Neurochem 2005;92:1033-1043. [PubMed: 15715654]

Bruzzone R, Hormuzdi SG, Barbe MT, Herb A, Monyer H. Pannexins, a family of gap junction proteins expressed in brain. Proc Natl Acad Sci U S A 2003;100:13644-13649. [PubMed: 14597722]

Cavelier P, Attwell D. Tonic release of glutamate by a DIDS-sensitive mechanism in rat hippocampal slices. J Physiol 2005;564:397-410. [PubMed: 15695241]

Chaudhry FA, Lehre KP, van Lookeren Campagne M, Ottersen OP, Danbolt NC, Storm-Mathisen J. Glutamate transporters in glial plasma membranes: highly differentiated localizations revealed by quantitative ultrastructural immunocytochemistry. Neuron 1995;15:711-720. [PubMed: 7546749]

Chen X, Wang L, Zhou Y, Zheng LH, Zhou Z. "Kiss-and-run" glutamate secretion in cultured and freshly isolated rat hippocampal astrocytes. J Neurosci 2005;25:9236-9243. [PubMed: 16207883]

Chung WJ, Lyons SA, Nelson GM, Hamza H, Gladson CL, Gillespie GY, Sontheimer H. Inhibition of cystine uptake disrupts the growth of primary brain tumors. J Neurosci 2005;25:7101-7110. [PubMed: 16079392] 
Contreras JE, Saez JC, Bukauskas FF, Bennett MV. Gating and regulation of connexin 43 (Cx43) hemichannels. Proc Natl Acad Sci U S A 2003;100:11388-11393. [PubMed: 13130072]

Contreras JE, Sanchez HA, Eugenin EA, Speidel D, Theis M, Willecke K, Bukauskas FF, Bennett MV, Saez JC. Metabolic inhibition induces opening of unapposed connexin 43 gap junction hemichannels and reduces gap junctional communication in cortical astrocytes in culture. Proc Natl Acad Sci U S A 2002;99:495-500. [PubMed: 11756680]

Crippa D, Schenk U, Francolini M, Rosa P, Verderio C, Zonta M, Pozzan T, Matteoli M, Carmignoto G. Synaptobrevin2-expressing vesicles in rat astrocytes: insights into molecular characterization, dynamics and exocytosis. J Physiol 2006;570:567-582. [PubMed: 16322057]

Del Castillo J, Katz B. Quantal components of the end-plate potential. J Physiol 1954;124:560-573. [PubMed: 13175199]

Dermietzel R, Gao Y, Scemes E, Vieira D, Urban M, Kremer M, Bennett MV, Spray DC. Connexin43 null mice reveal that astrocytes express multiple connexins. Brain Res Brain Res Rev 2000;32:4556. [PubMed: 10751656]

Domercq M, Brambilla L, Pilati E, Marchaland J, Volterra A, Bezzi P. P2Y1 receptor-evoked glutamate exocytosis from astrocytes: control by tumor necrosis factor-alpha and prostaglandins. J Biol Chem 2006;281:30684-30696. [PubMed: 16882655]

Duan S, Anderson CM, Keung EC, Chen Y, Chen Y, Swanson RA. P2X7 receptor-mediated release of excitatory amino acids from astrocytes. J Neurosci 2003;23:1320-1328. [PubMed: 12598620]

Ellershaw DC, Greenwood IA, Large WA. Dual modulation of swelling-activated chloride current by NO and NO donors in rabbit portal vein myocytes. J Physiol 528 Pt 2000;1:15-24.

Eskandari S, Zampighi GA, Leung DW, Wright EM, Loo DD. Inhibition of gap junction hemichannels by chloride channel blockers. J Membr Biol 2002;185:93-102. [PubMed: 11891568]

Evanko DS, Zhang Q, Zorec R, Haydon PG. Defining pathways of loss and secretion of chemical messengers from astrocytes. Glia 2004;47:233-240. [PubMed: 15252812]

Fellin T, Pozzan T, Carmignoto G. Purinergic receptors mediate two distinct glutamate release pathways in hippocampal astrocytes. J Biol Chem 2006;281:4274-4284. [PubMed: 16338906]

Fellin T, Pascual O, Gobbo S, Pozzan T, Haydon PG, Carmignoto G. Neuronal synchrony mediated by astrocytic glutamate through activation of extrasynaptic NMDA receptors. Neuron 2004;43:729743. [PubMed: 15339653]

Franke H, Grosche J, Schadlich H, Krugel U, Allgaier C, Illes P. P2X receptor expression on astrocytes in the nucleus accumbens of rats. Neuroscience 2001;108:421-429. [PubMed: 11738256]

Fremeau RT Jr, Burman J, Qureshi T, Tran CH, Proctor J, Johnson J, Zhang H, Sulzer D, Copenhagen DR, Storm-Mathisen J, Reimer RJ, Chaudhry FA, Edwards RH. The identification of vesicular glutamate transporter 3 suggests novel modes of signaling by glutamate. Proc Natl Acad Sci U S A 2002;99:14488-14493. [PubMed: 12388773]

Fumagalli M, Brambilla R, D’Ambrosi N, Volonte C, Matteoli M, Verderio C, Abbracchio MP. Nucleotide-mediated calcium signaling in rat cortical astrocytes: Role of $\mathrm{P} 2 \mathrm{X}$ and $\mathrm{P} 2 \mathrm{Y}$ receptors. Glia 2003;43:218-203. [PubMed: 12898701]

Gadea A, Lopez-Colome AM. Glial transporters for glutamate, glycine and GABA I. Glutamate transporters. J Neurosci Res 2001;63:453-460. [PubMed: 11241580]

Golovina VA. Visualization of localized store-operated calcium entry in mouse astrocytes. Close proximity to the endoplasmic reticulum. J Physiol 2005;564:737-749. [PubMed: 15731184]

Gonzalez A, Granados MP, Pariente JA, Salido GM. H2O2 mobilizes Ca2+ from agonist- and thapsigargin-sensitive and insensitive intracellular stores and stimulates glutamate secretion in rat hippocampal astrocytes. Neurochem Res 2006;31:741-750. [PubMed: 16794860]

Grimaldi M, Maratos M, Verma A. Transient receptor potential channel activation causes a novel form of [Ca 2+]I oscillations and is not involved in capacitative $\mathrm{Ca} 2+$ entry in glial cells. J Neurosci 2003;23:4737-4745. [PubMed: 12805313]

Hepp R, Perraut M, Chasserot-Golaz S, Galli T, Aunis D, Langley K, Grant NJ. Cultured glial cells express the SNAP-25 analogue SNAP-23. Glia 1999;27:181-187. [PubMed: 10417817]

Hofer A, Dermietzel R. Visualization and functional blocking of gap junction hemichannels (connexons) with antibodies against external loop domains in astrocytes. Glia 1998;24:141-154. [PubMed: 9700496] 
Hua X, Malarkey EB, Sunjara V, Rosenwald SE, Li WH, Parpura V. C(a2+)-dependent glutamate release involves two classes of endoplasmic reticulum $\mathrm{Ca}(2+)$ stores in astrocytes. J Neurosci Res 2004;76:86-97. [PubMed: 15048932]

Innocenti B, Parpura V, Haydon PG. Imaging extracellular waves of glutamate during calcium signaling in cultured astrocytes. J Neurosci 2000;20:1800-1808. [PubMed: 10684881]

Jeftinija SD, Jeftinija KV, Stefanovic G. Cultured astrocytes express proteins involved in vesicular glutamate release. Brain Res 1997;750:41-47. [PubMed: 9098527]

Jeftinija SD, Jeftinija KV, Stefanovic G, Liu F. Neuroligand-evoked calcium-dependent release of excitatory amino acids from cultured astrocytes. J Neurochem 1996;66:676-684. [PubMed: 8592139]

Jeremic A, Jeftinija K, Stevanovic J, Glavaski A, Jeftinija S. ATP stimulates calcium-dependent glutamate release from cultured astrocytes. J Neurochem 2001;77:664-675. [PubMed: 11299329]

Kimelberg HK. Astrocytic swelling in cerebral ischemia as a possible cause of injury and target for therapy. Glia 2005;50:389-397. [PubMed: 15846797]

Kimelberg HK, Goderie SK, Higman S, Pang S, Waniewski RA. Swelling-induced release of glutamate, aspartate, and taurine from astrocyte cultures. J Neurosci 1990;10:1583-1591. [PubMed: 1970603]

Kreft M, Stenovec M, Rupnik M, Grilc S, Krzan M, Potokar M, Pangrsic T, Haydon PG, Zorec R. Properties of $\mathrm{Ca}(2+)$-dependent exocytosis in cultured astrocytes. Glia 2004;46:437-445. [PubMed: 15095373]

Kukley M, Barden JA, Steinhauser C, Jabs R. Distribution of P2X receptors on astrocytes in juvenile rat hippocampus. Glia 2001;36:11-21. [PubMed: 11571780]

Lai CP, Bechberger JF, Thompson RJ, MacVicar BA, Bruzzone R, Naus CC. Tumor-suppressive effects of pannexin 1 in C6 glioma cells. Cancer Res 2007;67:1545-1554. [PubMed: 17308093]

Li S, Mealing GA, Morley P, Stys PK. Novel injury mechanism in anoxia and trauma of spinal cord white matter: glutamate release via reverse Na+-dependent glutamate transport. J Neurosci 1999;19:RC16. [PubMed: 10407058]

Liu HT, Tashmukhamedov BA, Inoue H, Okada Y, Sabirov RZ. Roles of two types of anion channels in glutamate release from mouse astrocytes under ischemic or osmotic stress. Glia 2006;54:343-357. [PubMed: 16883573]

Longuemare MC, Swanson RA. Excitatory amino acid release from astrocytes during energy failure by reversal of sodium-dependent uptake. J Neurosci Res 1995;40:379-386. [PubMed: 7745632]

Longuemare MC, Swanson RA. Net glutamate release from astrocytes is not induced by extracellular potassium concentrations attainable in brain. J Neurochem 1997;69:879-882. [PubMed: 9231751]

Maienschein V, Marxen M, Volknandt W, Zimmermann H. A plethora of presynaptic proteins associated with ATP-storing organelles in cultured astrocytes. Glia 1999;26:233-244. [PubMed: 10340764]

Malarkey EB, Parpura V. The role of TRPC1 in internal Ca2+ regulation in astrocytes. Biophysical Journal 2005;88:84A-85A.

McBean GJ. Cerebral cystine uptake: a tale of two transporters. Trends Pharmacol Sci 2002;23:299-302. [PubMed: 12119142]

Minelli A, Barbaresi P, Reimer RJ, Edwards RH, Conti F. The glial glutamate transporter GLT-1 is localized both in the vicinity of and at distance from axon terminals in the rat cerebral cortex. Neuroscience 2001;108:51-59. [PubMed: 11738130]

Mongin AA, Orlov SN. Mechanisms of cell volume regulation and possible nature of the cell volume sensor. Pathophysiology 2001;8:77-88. [PubMed: 11720802]

Mongin AA, Kimelberg HK. ATP potently modulates anion channel-mediated excitatory amino acid release from cultured astrocytes. Am J Physiol Cell Physiol 2002;283:C569-578. [PubMed: 12107067]

Mongin AA, Kimelberg HK. ATP regulates anion channel-mediated organic osmolyte release from cultured rat astrocytes via multiple Ca2+-sensitive mechanisms. Am J Physiol Cell Physiol 2005;288:C204-213. [PubMed: 15371260]

Mongin AA, Cai Z, Kimelberg HK. Volume-dependent taurine release from cultured astrocytes requires permissive [Ca(2+)](i) and calmodulin. Am J Physiol 1999;277:C823-832. [PubMed: 10516112] 
Montana V, Ni Y, Sunjara V, Hua X, Parpura V. Vesicular glutamate transporter-dependent glutamate release from astrocytes. J Neurosci 2004;24:2633-2642. [PubMed: 15028755]

Moran MM, Melendez R, Baker D, Kalivas PW, Seamans JK. Cystine/glutamate antiporter regulation of vesicular glutamate release. Ann N Y Acad Sci 2003;1003:445-447. [PubMed: 14684484]

Moran MM, McFarland K, Melendez RI, Kalivas PW, Seamans JK. Cystine/glutamate exchange regulates metabotropic glutamate receptor presynaptic inhibition of excitatory transmission and vulnerability to cocaine seeking. J Neurosci 2005;25:6389-6393. [PubMed: 16000629]

Nageotte J. Phenomenes de secretion dans le protoplasma des cellules nevrogliques de la substance grise. C R Soc Biol (Paris) 1910;68:1068-1069.

North RA. Molecular physiology of P2X receptors. Physiol Rev 2002;82:1013-1067. [PubMed: 12270951]

Parpura V, Haydon PG. Physiological astrocytic calcium levels stimulate glutamate release to modulate adjacent neurons. Proc Natl Acad Sci U S A 2000;97:8629-8634. [PubMed: 10900020]

Parpura V, Fang Y, Basarsky T, Jahn R, Haydon PG. Expression of synaptobrevin II, cellubrevin and syntaxin but not SNAP-25 in cultured astrocytes. FEBS Lett 1995a;377:489-492. [PubMed: 8549782]

Parpura V, Basarsky TA, Liu F, Jeftinija K, Jeftinija S, Haydon PG. Glutamate-mediated astrocyte-neuron signalling. Nature 1994;369:744-747. [PubMed: 7911978]

Parpura V, Liu F, Brethorst S, Jeftinija K, Jeftinija S, Haydon PG. Alpha-latrotoxin stimulates glutamate release from cortical astrocytes in cell culture. FEBS Lett 1995b;360:266-270. [PubMed: 7883045]

Pascual M, Climent E, Guerri C. BDNF induces glutamate release in cerebrocortical nerve terminals and in cortical astrocytes. Neuroreport 2001;12:2673-2677. [PubMed: 11522946]

Pascual O, Casper KB, Kubera C, Zhang J, Revilla-Sanchez R, Sul JY, Takano H, Moss SJ, McCarthy K, Haydon PG. Astrocytic purinergic signaling coordinates synaptic networks. Science 2005;310:113-116. [PubMed: 16210541]

Pasti L, Zonta M, Pozzan T, Vicini S, Carmignoto G. Cytosolic calcium oscillations in astrocytes may regulate exocytotic release of glutamate. J Neurosci 2001;21:477-484. [PubMed: 11160427]

Pelegrin P, Surprenant A. Pannexin-1 mediates large pore formation and interleukin-1beta release by the ATP-gated P2X7 receptor. Embo J 2006;25:5071-5082. [PubMed: 17036048]

Pizzo P, Burgo A, Pozzan T, Fasolato C. Role of capacitative calcium entry on glutamate-induced calcium influx in type-I rat cortical astrocytes. J Neurochem 2001;79:98-109. [PubMed: 11595762]

Pow DV. Visualising the activity of the cystine-glutamate antiporter in glial cells using antibodies to aminoadipic acid, a selectively transported substrate. Glia 2001;34:27-38. [PubMed: 11284017]

Re DB, Nafia I, Melon C, Shimamoto K, Kerkerian-Le Goff L, Had-Aissouni L. Glutamate leakage from a compartmentalized intracellular metabolic pool and activation of the lipoxygenase pathway mediate oxidative astrocyte death by reversed glutamate transport. Glia 2006;54:47-57. [PubMed: 16673373]

Rossi D, Brambilla L, Valori CF, Crugnola A, Giaccone G, Capobianco R, Mangieri M, Kingston AE, Bloc A, Bezzi P, Volterra A. Defective tumor necrosis factor-alpha-dependent control of astrocyte glutamate release in a transgenic mouse model of Alzheimer disease. J Biol Chem 2005;280:4208842096. [PubMed: 16253995]

Rossi DJ, Oshima T, Attwell D. Glutamate release in severe brain ischaemia is mainly by reversed uptake. Nature 2000;403:316-321. [PubMed: 10659851]

Rothstein JD, Dykes-Hoberg M, Pardo CA, Bristol LA, Jin L, Kuncl RW, Kanai Y, Hediger MA, Wang Y, Schielke JP, Welty DF. Knockout of glutamate transporters reveals a major role for astroglial transport in excitotoxicity and clearance of glutamate. Neuron 1996;16:675-686. [PubMed: 8785064]

Saez JC, Retamal MA, Basilio D, Bukauskas FF, Bennett MV. Connexin-based gap junction hemichannels: Gating mechanisms. Biochim Biophys Acta 2005;1711:215-224. [PubMed: 15955306]

Sanzgiri RP, Araque A, Haydon PG. Prostaglandin E(2) stimulates glutamate receptor-dependent astrocyte neuromodulation in cultured hippocampal cells. J Neurobiol 1999;41:221-229. [PubMed: 10512979] 
Seki Y, Feustel PJ, Keller RW Jr, Tranmer BI, Kimelberg HK. Inhibition of ischemia-induced glutamate release in rat striatum by dihydrokinate and an anion channel blocker. Stroke 1999;30:433-440. [PubMed: 9933284]

Shain WG, Martin DL. Activation of beta-adrenergic receptors stimulates taurine release from glial cells. Cell Mol Neurobiol 1984;4:191-196. [PubMed: 6091886]

Shanker G, Allen JW, Mutkus LA, Aschner M. The uptake of cysteine in cultured primary astrocytes and neurons. Brain Res 2001;902:156-163. [PubMed: 11384608]

Spray DC, Ye ZC, Ransom BR. Functional connexin "hemichannels": a critical appraisal. Glia 2006;54:758-773. [PubMed: 17006904]

Stigliani S, Zappettini S, Raiteri L, Passalacqua M, Melloni E, Venturi C, Tacchetti C, Diaspro A, Usai C, Bonanno G. Glia re-sealed particles freshly prepared from adult rat brain are competent for exocytotic release of glutamate. J Neurochem 2006;96:656-668. [PubMed: 16405496]

Stout CE, Costantin JL, Naus CC, Charles AC. Intercellular calcium signaling in astrocytes via ATP release through connexin hemichannels. J Biol Chem 2002;277:10482-10488. [PubMed: 11790776]

Szatkowski M, Barbour B, Attwell D. Non-vesicular release of glutamate from glial cells by reversed electrogenic glutamate uptake. Nature 1990;348:443-446. [PubMed: 2247147]

Takano T, Kang J, Jaiswal JK, Simon SM, Lin JH, Yu Y, Li Y, Yang J, Dienel G, Zielke HR, Nedergaard M. Receptor-mediated glutamate release from volume sensitive channels in astrocytes. Proc Natl Acad Sci U S A 2005;102:16466-16471. [PubMed: 16254051]

Tang XC, Kalivas PW. Bidirectional modulation of cystine/glutamate exchanger activity in cultured cortical astrocytes. Ann N Y Acad Sci 2003;1003:472-475. [PubMed: 14684492]

Trexler EB, Bennett MV, Bargiello TA, Verselis VK. Voltage gating and permeation in a gap junction hemichannel. Proc Natl Acad Sci U S A 1996;93:5836-5841. [PubMed: 8650179]

Volterra A, Bezzi P, Rizzini BL, Trotti D, Ullensvang K, Danbolt NC, Racagni G. The competitive transport inhibitor L-trans-pyrrolidine-2, 4-dicarboxylate triggers excitotoxicity in rat cortical neuron-astrocyte co-cultures via glutamate release rather than uptake inhibition. Eur J Neurosci 1996;8:2019-2028. [PubMed: 8921292]

Warr O, Takahashi M, Attwell D. Modulation of extracellular glutamate concentration in rat brain slices by cystine-glutamate exchange. J Physiol 1999;514(Pt 3):783-793. [PubMed: 9882750]

Wilhelm A, Volknandt W, Langer D, Nolte C, Kettenmann H, Zimmermann H. Localization of SNARE proteins and secretory organelle proteins in astrocytes in vitro and in situ. Neurosci Res 2004;48:249257. [PubMed: 15154671]

Ye ZC, Wyeth MS, Baltan-Tekkok S, Ransom BR. Functional hemichannels in astrocytes: a novel mechanism of glutamate release. J Neurosci 2003;23:3588-3596. [PubMed: 12736329]

Zeevalk GD, Davis N, Hyndman AG, Nicklas WJ. Origins of the extracellular glutamate released during total metabolic blockade in the immature retina. J Neurochem 1998;71:2373-2381. [PubMed: 9832135]

Zhang Q, Fukuda M, Van Bockstaele E, Pascual O, Haydon PG. Synaptotagmin IV regulates glial glutamate release. Proc Natl Acad Sci U S A 2004a;101:9441-9446. [PubMed: 15197251]

Zhang Q, Pangrsic T, Kreft M, Krzan M, Li N, Sul JY, Halassa M, Van Bockstaele E, Zorec R, Haydon PG. Fusion-related release of glutamate from astrocytes. J Biol Chem 2004b;279:12724-12733. [PubMed: 14722063] 

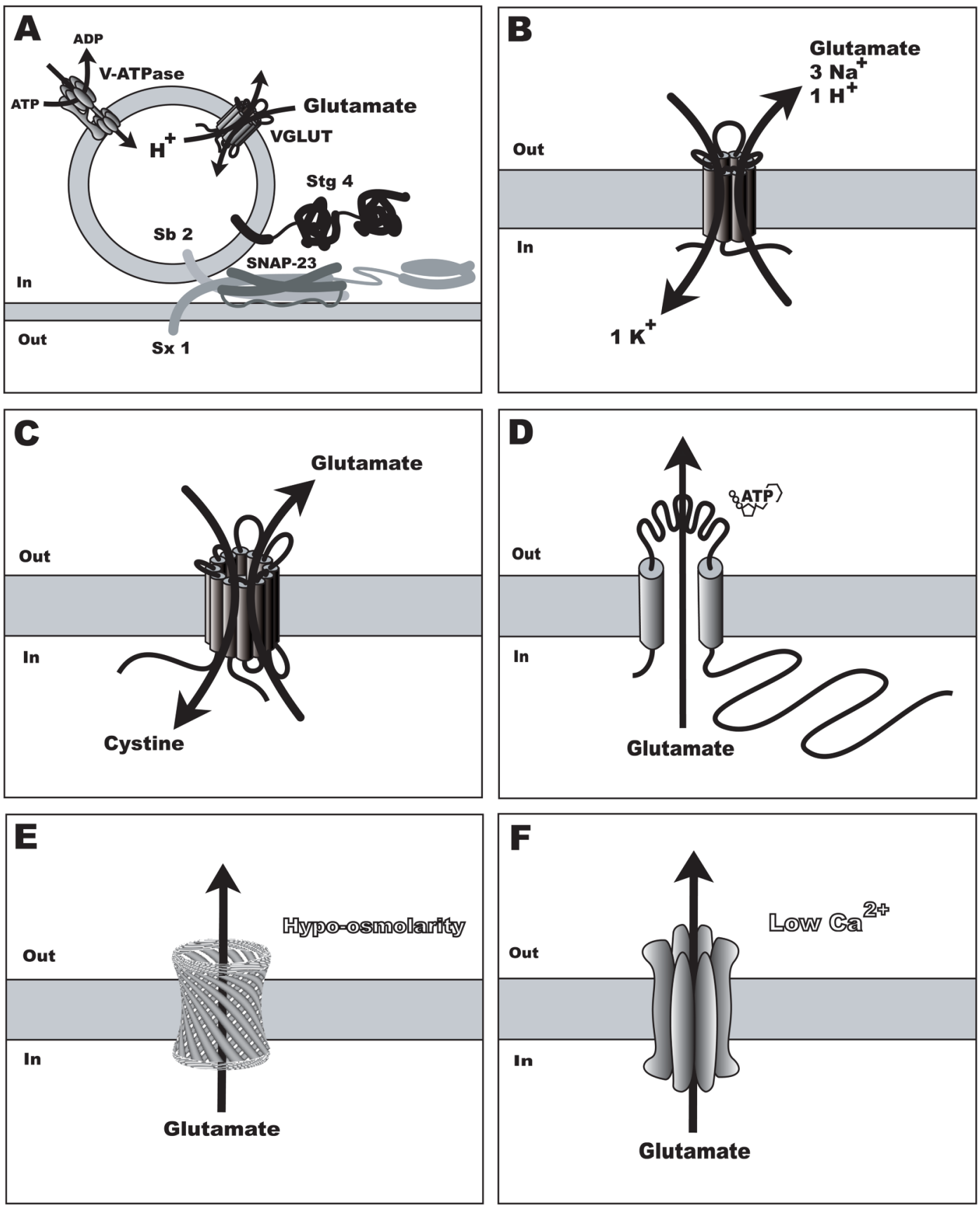

Figure 1. Mechanisms of glutamate release from astrocytes

A) $\mathrm{Ca}^{2+}$-dependent exocytosis, B) reversal of uptake by plasma membrane glutamate transporters, C) glutamate exchange via the cystine-glutamate antiporter, D) release through ionotropic purinergic receptors (only one subunit shown, but exchanger is believed to be multimeric), E) anion channel opening induced by cell swelling, F) release through functional unpaired connexons, 'hemichannels'. Abbreviations: Sb 2, synaptobrevin 2; SNAP-23, synaptosome-associated protein of $23 \mathrm{kDa}$; Stg 4, synaptotagmin 4; Sx 1, syntaxin 1; VATPase, Vacuolar type $\mathrm{H}^{+}$-ATPase; VGLUT, vesicular glutamate transporters. 
Table 1

Mechanisms of glutamate release from astrocytes and compounds shown to affect them

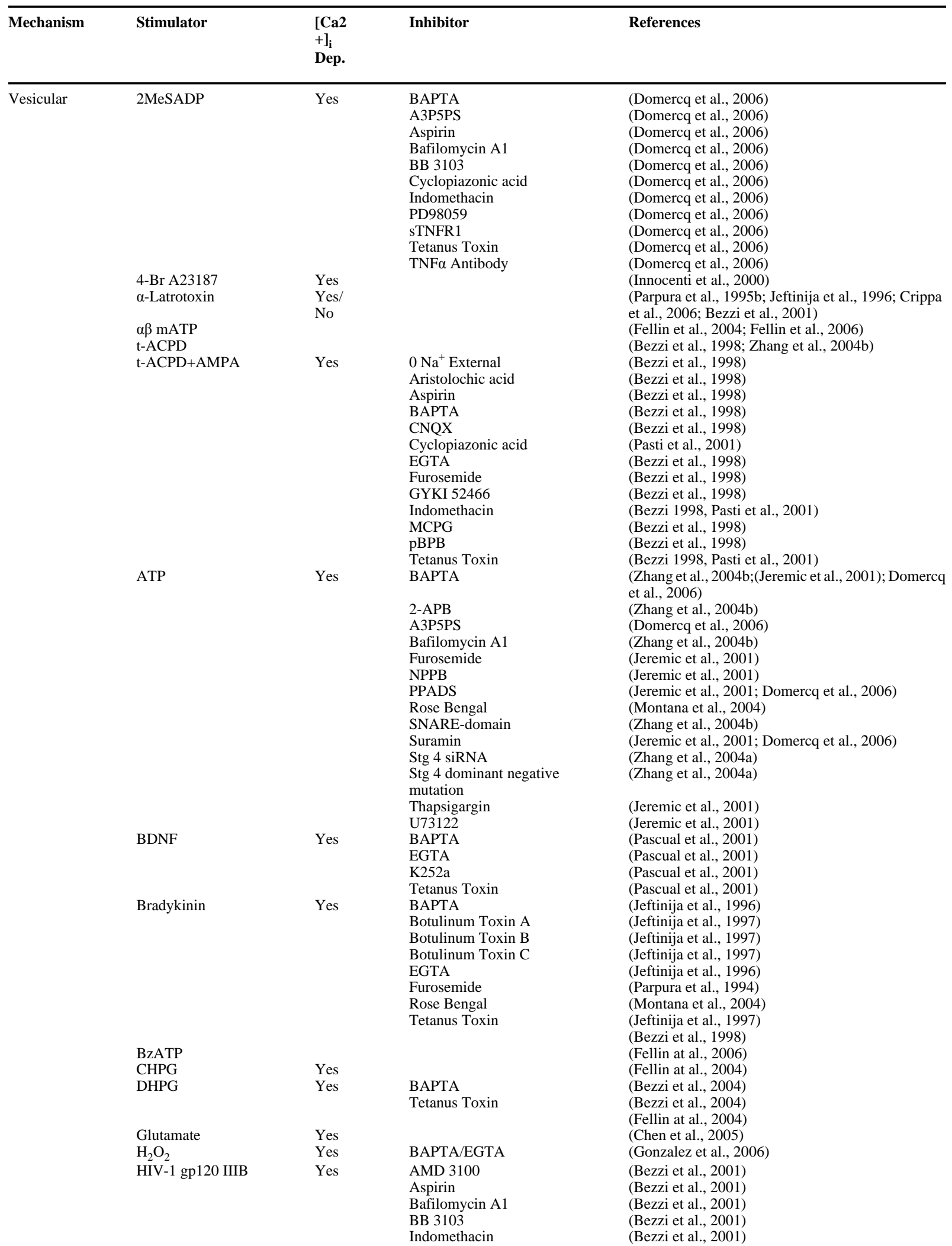




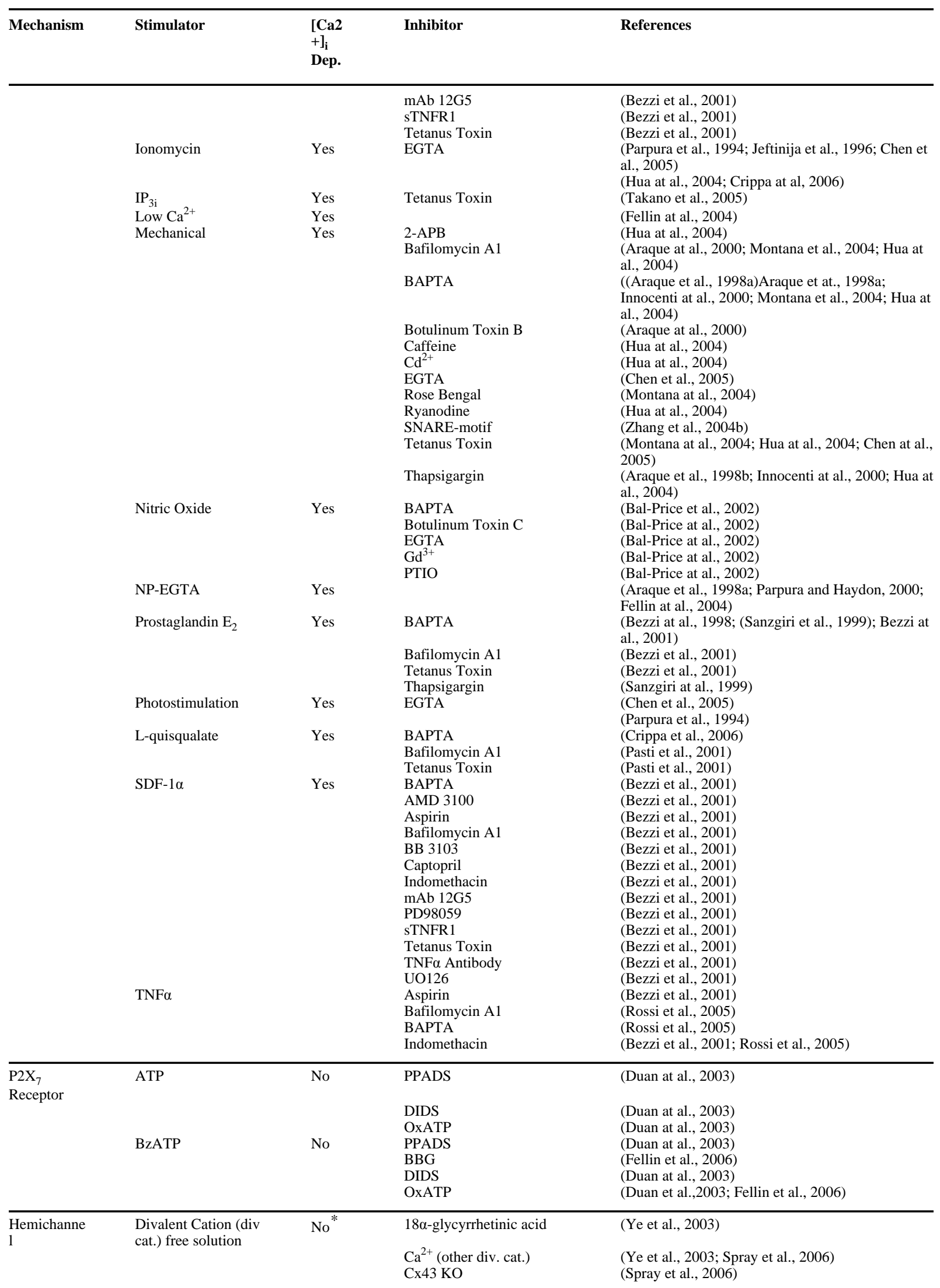




\begin{tabular}{|c|c|c|c|c|}
\hline Mechanism & Stimulator & $\begin{array}{l}{[\mathrm{Ca} 2} \\
+]_{\mathrm{i}} \\
\text { Dep. }\end{array}$ & Inhibitor & References \\
\hline & & & $\begin{array}{l}\text { Flufenamic acid } \\
\text { Heptanol } \\
\text { Hexanol } \\
\text { Octanol }\end{array}$ & $\begin{array}{l}\text { (Ye et al., 2003) } \\
\text { (Ye et al., 2003) } \\
\text { (Ye et al., 2003) } \\
\text { (Ye et al., 2003) }\end{array}$ \\
\hline $\begin{array}{l}\text { Anion Chan } \\
\text { nel }\end{array}$ & $\begin{array}{l}\text { Ouabain } \\
\text { 2DG/cyanide/IA } \\
\text { ATP }\end{array}$ & $\begin{array}{l}\text { No } \\
\text { No }\end{array}$ & $\begin{array}{l}\text { Arachadonic Acid } \\
\text { Flufenamic acid } \\
\text { Furosemide } \\
\text { Gd }^{3+} \\
\text { Gossypol } \\
\text { L-644,711 } \\
\text { NPPB } \\
\text { Phloretin } \\
\text { SITS } \\
\text { Tamoxifen } \\
\text { NPPB } \\
\text { NPPB } \\
\text { Arachadonic Acid } \\
\text { Gd } \\
\text { Phloretin } \\
\text { SITS } \\
\text { Tamoxifen } \\
\text { BAPTA } \\
\text { Flufenamic acid } \\
\text { Gossypol } \\
\text { Hyperosmolarity } \\
\text { NPPB } \\
\text { Reactive Blue } 2 \\
\text { Thapsigargin }\end{array}$ & $\begin{array}{l}\text { (Liu et al., 2006) } \\
\text { (Takano et al., 2005) } \\
\text { (Kimelberg et al., 1990) } \\
\text { (Liu et al., 2006) } \\
\text { (Takano et al., 2005) } \\
\text { (Kimelberg, et al., 1990) } \\
\text { (Takano et al., 2005; Liu et al., 2006) } \\
\text { (Liu et al., 2006) } \\
\text { (Kimelberg et al., 1990; Liu at al., 2006) } \\
\text { (Liu et al., 2006) } \\
\text { (Jeftinija et al., 1997; Zhang et al., 2004 }) \\
\text { (Basarsky et al., 1999) } \\
\text { (Liu et al., 2006) } \\
\text { (Liu et al., 2006) } \\
\text { (Liu et al., 2006) } \\
\text { (Liu et al., 2006) } \\
\text { (Liu et al., 2006) } \\
\text { (Liu et al., 2006) } \\
\text { (Takano et al., 2005) } \\
\text { (Takano et al., 2005) } \\
\text { (Takano et al., 2005) } \\
\text { (Takano et al., 2005) } \\
\text { (Takano et al., 2005) } \\
\text { (Takano et al., 2005) } \\
\text { (Takano et al., 2005) }\end{array}$ \\
\hline $\begin{array}{l}\text { Reverse Tra } \\
\text { nsport }\end{array}$ & $\begin{array}{l}\text { High } \mathrm{K}^{+} \text {external } \\
\\
\text { Fluoride/Azide } \\
\text { IA/Cyanide } \\
\text { PDC } \\
\text { TBHA } \\
\text { TBOA }\end{array}$ & $\begin{array}{l}\text { No } \\
\text { No }\end{array}$ & $\begin{array}{l}\text { D-Aspartate } \\
\text { Glutamate } \\
\mathrm{Na}^{+} \\
\text {SITS } \\
\text { PDC } \\
\text { PDC }\end{array}$ & $\begin{array}{l}\text { (Szatkowski et al., 1990) } \\
\text { (Szatkowski et al., 1990) } \\
\text { (Szatkowski at al., 1990; } \\
\text { (Longuemare et al., 1999) } \\
\text { (Longuemare et al., 1999) } \\
\text { (Longuemare et al., 1999) } \\
\text { (Zeevalk et al., 1998) } \\
\text { (Bezzi et al., 1998, Re et al., 2006) } \\
\text { (Kimelberg et al., 1990; Re et al., 2006) } \\
\text { (Re et al., 2006) }\end{array}$ \\
\hline $\begin{array}{l}\text { Cystine- } \\
\text { Glutamate } \\
\text { Antiporter }\end{array}$ & Cystine & No & $\begin{array}{l}\text { CPG } \\
\text { CPG } \\
\text { Homocysteic acid }\end{array}$ & $\begin{array}{l}\text { (Moran et al., 2003) } \\
\text { (Warr et al., 1999) } \\
\text { (Baker et al., 2002) } \\
\text { (Baker et al., 2002) }\end{array}$ \\
\hline
\end{tabular}

Abbreviations. 2-APB, 2-aminoethoxydiphenyl borate; 2DG, 2-Deoxy-D-glucose; 2MeSADP, 2-methylthio-adenosine diphosphate; $\alpha \beta$ mATP, $\alpha, \beta$ methylene ATP; A3P5PS, adenosine 3'-phosphate, 5'-phosphosulfate; AMPA, $\alpha$-amino-3-hydroxy-5-methyl-4-isoxazolepropionic acid; ATP, adenosine 5'-triphosphate; BAPTA, 1,2-bis(o-aminophenoxy)ethane-N,N, $N^{\prime}, N^{\prime}$-tetraacetic acid; BB 3103, a blocker of the TNF $\alpha$-converting enzyme; BBG, Brilliant Blue G; BDNF, brain-derived neurotrophic factor; BzATP, 3'-O-(4-benzoyl)benzoyl adenosine 5'-triphosphate; CHPG, 2-chloro-5-hydroxyphenylglycine; CNQX, 6-cyano-7-nitroquinoxaline-2,3-dione; Cx43 KO, Connexin 43 knockout mouse; Dep., dependent; DHPG, 3,5-dihydroxyphenylglyine; DIDS, 4,4'-diisothiocyanatostilbene-2,2'-disulphonic acid; EGTA, ethylene glycol tetraacetic acid; GYKI 52466, 1-(4-Aminophenyl)-4-methyl-7,8methylenedioxy-5H-2,3-benzodiazepine hydrochloride; HIV-1 gp120 IIIB, human immunodeficiency virus type 1 gp120(IIIB) protein; IA, Indoacetic acid; IP3i, intracellular inositol 1,4,5-trisphosphate; L-644,711, ((5,6-dichloro-2,3,9,9a-tetrahydro-3-oxo-9a-propyl-1H-fluoren-7-yl)oxy)acetic acid; mAb 12G5, anti-chemokine (C-X-C motif) receptor 4 monoclonal antibody; MCPG, $\alpha$-methyl-4-carboxyphenylglycine; NP-EGTA, o-nitrophenyl ethylene glycol tetraacetic acid; NPPB, 5-nitro-2-(3-phenylpropylamino)benzoic acid; OxATP, adenosine 5'-triphosphate-2',3'-dialdehyde; pBPB, 4bromophenacyl bromide; PD98059, 2'-amino-3'-methoxyflavone; PDC, 1-trans-pyrrolidine-2,4-dicarboxylate; PPADS, pyridoxal-phosphate-6azophenyl-2',4'-disulfonate; PTIO, 2-(4-carboxyphenyl)-4,4,5,5-tetramethylimidazoline-1-oxyl-3-oxide; SDF-1 $\alpha$, stromal cell-derived factor-1 $\alpha$; SITS, 4-acetamido-4'-isothiocyanostilbene-2,2'-disulfonic acid; SNARE-domain, synaptobrevin 2 amino acids 1-96; Stg 4 siRNA, synaptotagmin 4 small interfering RNA; sTNFR1, soluble tumor necrosis factor-receptor 1; t-ACPD, trans-( \pm )-1-amino-1,3-cyclopentanedicarboxylate; TBHA, L-threo- $\beta$ hydroxyaspartate; TBOA, DL-threo-beta-benzyloxyaspartate; TNF $\alpha$, tumor necrosis factor $\alpha$; U73122, 1-(6-(17 $\beta$-3-methoxyestra-1,3,5(10)-trien-17-yl) amino)hexyl)-1H-pyrrole-2,5-dione.

* Connexin hemichannel opening is achieved in low extracellular $\mathrm{Ca}^{2+}$. 